et al., 1972; Small et al., 1972) and the propensity to form gall stones after ileal resection (Heaton and Read, 1969).

In conclusion, the data on the enterohepatic circulation of cholate in coeliac and cholecystectomy patients and control subjects suggest that the large pools in coeliac patients and the small pools in cholecystectomy and probably also in gall stone patients are primarily due to changes in frequency of enterohepatic circulation of the pool. This hypothesis is shown diagrammatically in fig. 3.

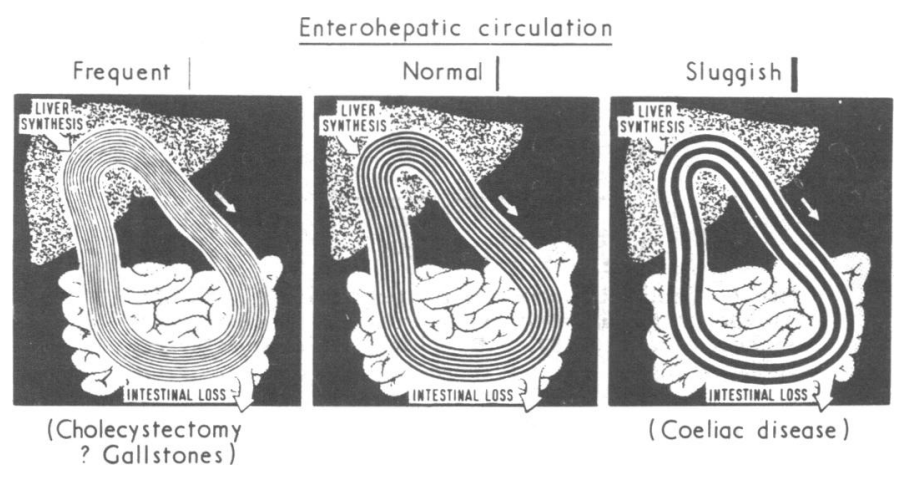

FIG. 3-Schematic representation of relation between number of times bile salt pool circulates (No. of lines) and size of pool (thickness of lines) when sait pool circulates (No. of lines) and size of pool (thickness of lines) when (total width of bands) is same in each case; so is proportion excreted and (total width of bands) is same in each case; so is proportion excreted and
therefore total daily synthesis. (Contrast with scheme in Hofmann, 1967, showing effects of broken enterohepatic circulation.)

\author{
References \\ Admirand, W. H., and Small, D. M. (1968). Fournal of Clinical Investigation, \\ 47, 1043.
}

Austad, W. I., Lack, L., and Tyor, M. P. (1967). Gastroenterology, 52, 638. Bell, C. C., et al. (1972). Surgery, Gynecology and Obstetrics, 134, 473.

Bergström, S., and Danielsson, H. (1968). In Handbook of Physiology, section 6, vol. V, p. 2391. Washington, D.C., American Physiological Society.

Boyd, G. S., and Eastwood, M. A. (1968). Biochimica Biophysica Acta, 15, 159.

Brunner, H., Hofmann, A. F., and Summerskill, W. H. J. (1972). Gastroenterology, 62, 188.

Danzinger, R. G., Hofmann, A. F., Schoenfield, L. J., and Thistle, J. L. (1972). New England fournal of Medicine, 286, 1

Di Magno, E. P., Go, V. L. W., and Summerskill, W. H. J. (1972). Gastroenterology, 63, 25 .

Dowling, R. H., Bell, G. D., and White, J. (1972). Gut, 13, 415.

Grundy, S. M., Metzger, A. L., and Adler, R. D. (1972). Fournal of Clinical Investigation, 51, 3026

Heaton, K. W. (1972). Bile Salts in Health and Disease. Edinburgh, Churchill

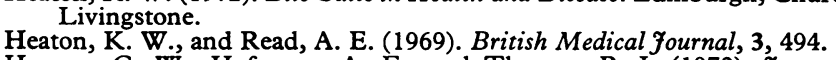

Hepner, G. W., Hofmann, A. F., and Thomas, P. J. (1972). Fournal of Clinical Investigation, 51, 1889 .

Hofmann, A. F. (1967). Gastroenterology, 52, 752.

Hofmann, A. F., Schoenfield, L. J., Kottke, B. A., and Poley, J. R. (1970). In Methods in Medical Research, vol. XII, p. 149. Chicago, Year Book Medical Publishers.

Hofmann, A. F., Northfield, T. C., and Thistle, J. L. (1973). New England

Fournal of Medicine, 288, 46.
Low-Beer, T. S., Heaton, K. W., Heaton, S. T., and Read, A. E. (1971). Lancet, 1, 991 .

Low-Beer, T. S., Pomare, E. W., and Morris, J. S. (1972). Nature New Biology, 238, 215.

Low-Beer, T. S., Heaton, K. W., Pomare, E. W., and Read, A. E. (1973).,

Gut, 14, 204.
Malagelada, J. R., Go, V. L. W., Gamble, W. S., and Summerskill, W. H. J. (1972). Gastroenterology, 62, 780.

Mosbach, E. H. (1972). Archives of Internal Medicine, 130, 478.

Pomare, E. W., and Heaton, K. W. (1973). In preparation.

Sarles, H., et al. (1969). American fournal of Digestive Diseases, 14, 531.

Schaffer, E. A., Braasch, J. W., and Small, D. M. (1972). New England Fournal of Medicine, 287, 1317.

Simmons, F., Ross, A. P. J., and Bouchier, I. A. D. (1972). Gastroenterology, 63, 466.

Small, D. M., Dowling, R. H., and Redinger, R. N. (1972). Archives of Internal Medicine, 130, 552.

van Deest, B. W., Fordtran, J. S., Morawski, S. G., and Wilson, J. D. (1968). Fournal of Clinical Investigation, 47, 1314.

Vlahcevic, Z. R., Bell, C. C., Buhac, I., Farrar, J. T., and Swell, L. (1970). Gastroenterology, 59, 165.

Vlahcevic, Z. R., et al. (1972). Gastroenterology, 62, 73.

\title{
Plasma Osmolality and Feeding Practices of Healthy Infants in First Three Months of Life
}

\author{
D. P. DAVIES
}

British Medical fournal, 1973, 2, 340-342

\section{Summary}

Plasma osmolality was measured in 60 healthy infants aged 1 to 3 months. The mean plasma osmolality in the 14 breast-fed infants (group $A$ ) was $284.3 \mathrm{mOsm} / 1$. Nine infants fed artificial milk formulae alone (group B) had a mean value of $293.8 \mathrm{mOsm} / 1 . ; 37$ infants already receiving solid foods in addition to artificial milk formulae (group C) had a mean value of $297 \cdot 1 \mathrm{mOsm} / 1$. The number of individual observations in the hyperosmolar range (more than $300 \mathrm{mOsm} / 1$.) in groups $\mathbf{A}, \mathbf{B}$, and $\mathbf{C}$ were 0 , 1 , and 15, accounting respectively for $0 \%, 11 \cdot 1 \%$, and $\mathbf{4 0 . 5} \%$ of the total number of observations in each group.

These results suggest that the early introduction to solid foods and the widespread use of artificial milk formulae

\footnotetext{
Department of Child Health, Welsh National School of Medicine, Cardifi CF4 4XN

D. P. DAVIES, M.R.C.P., D.C.H., Lecturer
}

at the expense of breast-feeding during the first three months of life result in an excessive dietary solute intake. This considerably stretches the ability of the immature kidney to maintain normal plasma tonicity. Minimal loss of water could precipitate a dangerous situation for babies with hyperosmolar plasma.

\section{Introduction}

Feeding practices for young infants have undergone considerable changes in recent years, with artificial dried milk formulae largely replacing breast-feeding, and solid foods being introduced at a much earlier age than was previously recommended (Taitz, 1971). It has also been suggested more recently (Taitz and Byers, 1972) that another feeding practice has insidiously developed-namely, a tendency for mothers to use excessive amounts of dried milk powder when reconstituting the feed so that milk formulae which are much too concentrated are offered to young infants. There is little doubt that artificial milk feeds and the early introduction of solid food can be held responsible for the greatly increased incidences of excessive weight gain in early infancy (Taitz, 1971), but the practice of preparing artificial milk feeds from heaped scoops instead of complying with the 
manufacturer's advice could hold more sinister implications. Thus it has been suggested (Taitz and Byers, 1972) that the resulting high solute feed might be an important factor in the aetiology of hypernatraemic dehydration, either in an isolated form or else associated with infantile gastroenteritis.

It must, however, be remembered that even when most dried milk formulae are correctly reconstituted they still provide a dietary solute load which is at least twice that of human breast milk (Fomon, 1967). Furthermore, most infant cereals and commercially manufactured solid foods are also potential sources of high solute intake since they contain high quality protein (Shukla et al., 1972). Excessive dietary solute intake is therefore likely to be more widespread among British infants than is currently realized, and a recent study (Shukla et al., 1972) of normal infants in the Midlands has in fact shown that the average daily protein intake in infants during the first year of life is markedly higher than the recommendation by the Department of Health and Social Security (1970). The ability of the infant to cope with an increased solute load is less than that of an adult because during the first few months of life the kidney is still in a relatively immature state with a lower glomerular filtration rate limiting its ability to deal with the stress of high solute loading (Edelmann and Spitzer, 1969). Apparently healthy infants therefore might be on the verge of a hyperosmolar crisis from only the mild degree of water loss accompanying any of the common infections of infancy.

To test this hypothesis the plasma osmolality in a group of young healthy infants has been measured and related to the individual methods of feeding. Plasma osmolality is a reliable index of the capacity of the infant kidney to manage dietary solute load (D. P. Davies, unpublished data, 1972) and therefore appears to be an appropriate biochemical parameter to study in this context.

\section{Material and Methods}

The 60 infants included in this study were an unselected sample of healthy infants aged between 1 and 3 months who attended one of the Cardiff local authority health clinics. A feeding history was obtained from the mothers and the purpose and nature of the investigation was carefully explained. Capillary blood was collected by heel-prick with particular care being taken to avoid unnecessary squeezing of the heel. The time between sampling and the previous feed was variable, but in no instance was it less than one hour.

The specimens were centrifuged within three hours of collection. The plasma was separated and the plasma osmolality was determined immediately by the method of freezing point depression, using the Knauer Semimicro-osmometer. The definitive measurement was the mean of duplicate observations.

\section{Results}

The infants were divided into three groups depending on how they were fed at the time of attending the local authority clinic. Group A included infants who were breast-fed, group B were those fed on dried milk formulae alone, and group $\mathrm{C}$ were those who had already received infant cereals and other solid foods in addition to their artificial milk. The mean age and distribution of the infants among these groups is shown in table I.

TABLE I-Mean Age and Distribution among the Three Feeding Groups of the 60 Infants Studied

\begin{tabular}{c|c|c}
\hline Clinical Groups & $\begin{array}{c}\text { No. in } \\
\text { Group }\end{array}$ & $\begin{array}{c}\text { Mean Age on Day of Study } \\
\text { (Weeks) }\end{array}$ \\
\cline { 1 - 2 } A & 14 & $8 \cdot 4$ \\
B & 99 & 7.9 \\
C & 37 & $8 \cdot 2$
\end{tabular}

The individual observations for plasma osmolality are shown in the chart and the results are summarized in table II. For the 14 breast-fed infants the mean plasma osmolality was $284.3 \mathrm{mOsm} / 1$. (S.E. 1.21). The nine infants on the dried milk formulae alone had a mean value of $293.8 \mathrm{mOsm} / 1$. (S.E. 1.60), and the value for the 37 infants on a mixed feeding regimen was $297 \cdot 1 \mathrm{mOsm} / 1$. (S.E. 1.85). The mean osmolality of groups $B$ and $C$ both differed significantly from that of group A ( $P<0.001$ in both instances). The difference between the mean values of groups $\mathrm{B}$ and $\mathrm{C}$ did not reach statistical significance.

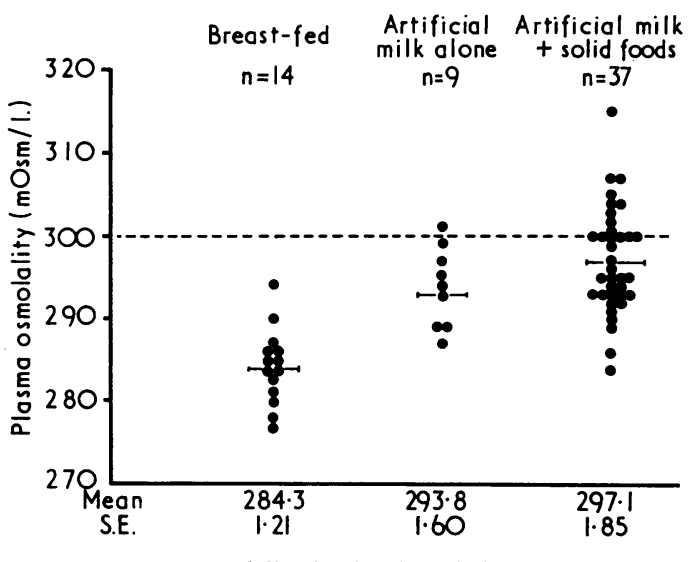

Plasma osmolality in the three infant groups.

TABLE II-Plasma Osmolality in the Three Infant Groups. Mean Values $( \pm$ S.E.

\begin{tabular}{|c|c|c|c|}
\hline $\begin{array}{l}\text { Clinical group } \\
\text { Plasma osmolality }(\mathrm{mOsm} / 1 .)\end{array}$ & $284 \cdot 3^{\mathrm{A}}(1 \cdot 21)$ & $\stackrel{B}{B}$ & $\underset{297 \cdot 1(1 \cdot 85)^{*}}{C}$ \\
\hline
\end{tabular}

*When compared with group $\mathrm{A}, \mathrm{P}<0.001$

*When compared with group A, $P<0.001$.
The difference between Group $B$ and Group $C$ is not signficant $(P>0.05)$

Since the definition of a hyperosmolar state requires a minimum plasma osmolality of $300 \mathrm{mOsm} / \mathrm{l}$. (Rapoport, 1947), it was thought important to determine the number of individual observations falling into this range in each of the three groups (table III). In group A there were no individual observations

TABLE III-Plasma Osmolality. Individual Observations greater than 300 $m O s m / l$.

\begin{tabular}{c|c|c}
\hline Clinical Group & $\begin{array}{c}\text { No. in } \\
\text { Group }\end{array}$ & Bercentage of Total Observations \\
\hline A & 0 & 0 \\
B & 1 & $11 \cdot 1$ \\
15 & $40 \cdot 5^{*}$
\end{tabular}

*When compared with groups $\mathrm{A}$ and $\mathrm{B}, \mathrm{P}<0.001$ and $<0.05$ respectively.

above or including $300 \mathrm{mOsm} / \mathrm{l}$. In groups $\mathrm{B}$ and $\mathrm{C}$ there were respectively one and 15 such individual observations, which accounted for $11.1 \%$ and $40.5 \%$ of the total observations in each of these groups. When compared with group A only the percentage in group $C$ reached statistical significance $(P<$ $0.001)$. There was also a significant difference between the proportions in groups $\mathrm{B}$ and $\mathrm{C}(\mathrm{P}<0.05)$.

\section{Discussion}

The raised plasma osmolality in the infants who were fed either dried milk formulae alone, or milk formulae with additional solid foods, suggests that in these infants the physiological mechanisms which are responsible for maintaining plasma 
osmolality within the normal range are considerably stretched when compared with the situation in breast-fed infants. These observations assume great importance when it is remembered that plasma osmolality is among the most jealously guarded of the body's chemical parameters (Rapoport, 1947). It is likely that an interaction between the increased dietary solute load provided by the foods and the relatively immature function of the infant kidney is responsible. It has, however, always been assumed that the greatly increased osmolar load provided by cows' milk formulae is well tolerated by the young healthy infant (Taitz and Byers, 1972). This must be true since most infants when fed in this way develop normally without mishap. Nevertheless, the high solute load obligates, even under normal healthy conditions, an increased renal water requirement for its excretion (Pratt and Snyderman, 1953). If additional solute is given in the form of non-milk infant foods then even greater demands are made on the renal reserves, and this situation is likely to be aggravated since the volume of fluid ingested by the young infant tends to decrease as the calorie concentration of the food increases (Zeigler and Fomon, 1970). That this situation exists is shown by the present study where 15 of the 37 infants $(40.5 \%)$ who had already been introduced to a mixed feeding regimen in the first three months of life had individual plasma osmolalities in the hyperosmolar range, compared with only one $(11.1 \%)$ in the group fed milk formulae alone and none in the breast-fed infants.

The hypothesis tested in this study-namely, that the combination of artificial milk preparations with the early introduction of solid infant foods provides the infant with a dietary solute load which greatly stresses the capacity of the kidney to maintain the normal tonicity of body fluids-appears to be correct. What are the implications ?

Plasma hyperosmolality complicating infantile gastroenteritis has commonly been recognized since 1947 (Macaulay and Blackhall, 1961), and in a survey of infantile gastroenteritis in Manchester (Ironside et al., 1970) as many as $63 \%$ of 75 dehydrated infants in whom the serum sodium was measured were found to have hypernatraemia - a sodium level above $150 \mathrm{mEq} / 1$., equivalent to more than $300 \mathrm{mOsm} / \mathrm{l}$. There is, furthermore, little doubt that body fluid hypertonicity can also arise in infancy from the excessive loss of water which might occur with any febrile condition (Ziegler and Fomon, 1971) or from the "injudicious use of highly concentrated milk feeds" (Stern et al., 1972), and when it is remembered that permanent neurological damage can result from these hyperosmolar states of infancy (Macaulay and Watson, 1967; Morris-Jones et al., 1967) these observations assume much importance. This study suggests, however, that the greatly increased solute load which is provided by the combination of early mixed feeding with artificial milk formulae produces even in apparently healthy infants an alarmingly high proportion who are already in an asymptomatic hyperosmolar state. In these only minimal water loss (as might be expected with any of the common infant infections) would be sufficient to precipitate a potentially dangerous situation. The protective nature of breast-feeding is evident since the low values for plasma osmolality in the breastfed infants suggests a much greater reserve capacity to cope with states of water loss.

It is perhaps too idealistic a philosophy to expect all infants to be breast-fed, and at the present time it must be accepted that artificial feeding is now an established way of life in $80 \%$ of the nation's babies (Davies, 1971). Instead, it is important that all doctors and nurses responsible for the care of the mother and newborn infant are aware of certain fundamental principles of infant feeding, and in particular the potential dangers which can accompany the too early introduction of solid foods. It is all too easy for the young infant to acquire bad and potentially hazardous feeding habits, but once acquired these are lost only with difficulty and not without considerable distress to the mother. It is regrettable, therefore, that all too often seeds of bad habit are sown by members of the medical or nursing profession. The advice frequently given to introduce infants to non-milk foods during the first weeks of life merely to keep them "contented" is often the beginning of an insidious accumulation of solute and must be totally deprecated. The counsel given by Davies (1971) should therefore be heeded-namely, that milk alone is satisfactory for adequate growth, probably until 4 to 5 months, and that the introduction of mixed feeding before 3 months at the earliest is unnecessary and probably undesirable.

I wish to thank Dr. D. J. Anderson, medical officer of health, and the nursing and medical staff of the Roath Court Clinic in Cardiff for their invaluable help throughout, Mrs. D. Williams for her help in obtaining the blood samples, Professor O. P. Gray for his valuable criticism and advice, Mrs. M. Johnson for secretarial help, and all the mothers who so cheerfully allowed their babies to be studied.

\section{References}

Davies, P. A. (1971). British Medical fournal, 4, 351 . and Medical Subjects, No. 120. London, H.M.S.O.

Edelmann, C. M., jun., and Spitzer, A. (1969). Fournal of Pediatrics, 75, 509. Fomon, S. J. (1967). Infant Nutrition. Philadelphia, Saunders.

Ironside, A. G., Tuxford, A. F., and Heyworth, B. (1970). British Medical Fournal, 3, 20.

Macaulay, D., and Blackhall, M. I. (1961). Archives of Disease in Childhood, 36, 543. Macaulay, D., and Watson, M. (1967). Archives of Disease in Childhood, 42,
485.

Morris-Jones, P. H., Houston, I. B., and Evans, R. C. (1967). Lancet, 2, 1385.

Pratt, E. L., and Snyderman, S. E. (1953). Pediatrics, 11, 65.

Rapoport, S. (1947). American Fournal of Diseases of Children, 74, 682.

Shukla, A., Forsyth, H. A., Anderson, C. M., and Marwah, S. M. (1972). British Medical fournal, 4, 507.

Stern, G. M., Jones, R. B., and Fraser, A. C. L. (1972). Archives of Disease in Childhood, 47, 468.

Taitz, L. S. (1971). British Medical Fournal, 1, 315 .
Taitz, L. S., and Byers, H. D. (1972). Archives of Disease in Childhood, 47,

Ziegler, E. E., and Fomon, S. J. (1971). Fournal of Pediatrics, 78, 561. 